\title{
Hindi translation and evaluation of psychometric properties of Craig Hospital Inventory of Environmental Factors instrument in spinal cord injury subjects
}

\author{
Sandeep Soni, Shefali Walia, Majumi Mohamad Noohu ${ }^{1}$ \\ Department of Physiotherapy, ISIC Institute of Rehabilitation Sciences, ${ }^{1}$ Centre for Physiotherapy and Rehabilitation Sciences, Jamia Millia Islamia, \\ New Delhi, India
}

\begin{abstract}
Introduction: The Craig Hospital Inventory of Environmental Factors instrument (CHIEF) is one of the few tools to assess the environmental barriers. The purpose of this study was to translate long and short CHIEF into Hindi language, and to determine its validity and reliability. Design and Setting: The study design was observational case series with repeated measures. It was carried out at Indian Spinal Injuries Centre New Delhi, a specialized center for rehabilitation for spinal cord injury. Methods: The CHIEF instrument was translated from English to Hindi based on the Beaton guidelines for the cross-cultural adaptation of health status measures. The Hindi version of the CHIEF instrument was then administered on a convenience sample of 30 spinal cord injured subjects. Its content validity, internal consistency, test-rest reliability (intraclass correlation coefficient [ICC] 2,1), standard error of measurement (SEM), and minimum detectable change (MDC) were determined for both the longer and shorter version. Results: The mean \pm SD of total of Hindi-CHIEF instrument, longer version was $1.44 \pm 0.82$ and total score of the shorter version was $1.07 \pm 0.66$. The content validity determined by the content validity ratio was found to be 1 for all the items except item number 5,11 , and 12. The content validity index was 0.97 for the longer version and for the shorter version it was 0.98 . Internal consistency, Cronbach's $\alpha$ value was found to be 0.92 and test-retest value (ICC 2,1) was $0.80(P<0.001)$. The MDC was found to be 0.99 and SEM was 0.36 for the longer version. The Cronbach's $\alpha$ was 0.731, ICC 2,1 was $0.63(P<0.001)$, SEM was 0.24 , and MDC was 0.66 for the shorter version. Conclusion: The Hindi translated version of the CHIEF scale has acceptable content validity and reliability. It can be used to assess environmental barriers perceived by spinal cord injury patients.
\end{abstract}

Key words: Barriers, participation, reliability, spinal cord injury, validity

\section{Introduction}

Spinal cord injury can lead to motor and sensory deficit along with bowel and bladder dysfunction. It can cause activity limitation and participation restriction. ${ }^{[1]}$ It is well-known that the environment is a major domain of well-being or quality of life. ${ }^{[2]}$ Successful community

Address for correspondence:

Asst Prof. Majumi Mohamad Noohu, Centre for Physiotherapy and Rehabilitation Sciences, Jamia Millia Islamia, New Delhi, India. E-mail: mnoohu@jmi.ac.in

\begin{tabular}{|l|l|}
\hline \multicolumn{2}{|c|}{ Access this article online } \\
\hline Quick Response Code: & Website: \\
\hline & www.ruralneuropractice.com \\
\cline { 2 - 2 } & \\
\hline
\end{tabular}

integration in spinal cord injured can be defined as being part of the mainstream of family and community life, fulfilling normal roles and responsibilities, and being an active and contributing member of one's social groups and society as a whole following rehabilitation interventions. ${ }^{[3,4]}$ The interaction between the individual and the environment play a key role in determining the level of participation in society. ${ }^{[2]}$ According to the International Classification of Functioning, Disability and Health by $\mathrm{WHO}$, the environment barriers are considered to be important, because the "social

This is an open access article distributed under the terms of the Creative Commons Attribution-NonCommercial-ShareAlike 3.0 License, which allows others to remix, tweak, and build upon the work non-commercially, as long as the author is credited and the new creations are licensed under the identical terms.

For reprints contact: reprints@medknow.com

How to cite this article: Soni S, Walia S, Noohu MM. Hindi translation and evaluation of psychometric properties of Craig Hospital Inventory of Environmental Factors instrument in spinal cord injury subjects. J Neurosci Rural Pract 2016;7:13-22. 
participation" of people with impairments would be facilitated by the prevention and reduction of environmental barriers. ${ }^{[5]}$

To obtain a clearer understanding of environmental barriers faced by patients after spinal cord injury and to better assess the effect of intervention programs, a standardized assessment of environmental factors is essential. The 25-item self administered Craig Hospital Inventory of Environmental Factors (CHIEF) developed by Whiteneck et al., is a common tool used to assess environmental barriers in people with spinal cord injury and other disabilities. It has demonstrated good psychometric properties in samples of people with and without disabilities. CHIEF addresses both the frequency and magnitude of the environmental barriers encountered, and covers five different domains (i.e., physical, attitudinal, service, productivity, and policy) of barriers that hinder people from doing what they need and want to do. In contrast to other environment assessment tools, the CHIEF instrument was designed as a shorter inventory of only environmental barriers not facilitators. The CHIEF instrument has a shorter version also which was developed from the longer version by retaining 12 questions. ${ }^{[6]}$

With a population of more than 1 billion and the national language being Hindi, a majority of people speak Hindi in India. Apart from India, there is large number of Indians who are settled in various parts of the world and have Hindi as their mother tongue. The prevalence of spinal cord injury in India is high, ${ }^{[7]}$ and there is no of tools for assessing environmental barriers for such a large Hindi-speaking population in their native language. Clinically, having standardized assessment tools available in Hindi with proven psychometric properties will assist the clinicians in providing culturally sensitive assessment to clients who do not understand English. Hence, this study aimed to translate the commonly used CHIEF instrument to Hindi language and to determine its validity and reliability for assessing environmental barriers in spinal cord injured.

\section{Methods}

A convenience sample of 30 subjects with spinal cord injury who met the inclusion and exclusion criteria were recruited from Indian Spinal Injuries Centre, New Delhi. The study was approved by the Institute's Research Review and Ethics Committee. Permission was taken from the original developers to translate the CHIEF instrument from English to Hindi. Inclusion criteria for selection were subjects with spinal cord injury of duration more than 1 year ${ }^{[8]}$ (American Spinal Injury Association [ASIA] Scale A, B, C, and D) and those who were able to read and understand Hindi. Subjects diagnosed with any medical, psychiatric illness, or any other neurological impairment which might hamper his/her participation in the study was excluded.

The Beaton translation guidelines was used for the translation of CHIEF instrument. ${ }^{[9]}$ The instrument was translated into Hindi by a translation committee, which comprised two translators working as professional translators. All the translators had Hindi as their native language and a very good command over English. Translator 1 and 2 translated the instrument into Hindi, translators 3 and 4 back-translated the scale into English. This back translation was produced by two persons with the source language (English) as their mother tongue. A moderator was appointed to coordinate the whole process, and was involved in both, the forward translation and the back translation processes. The instrument was then reviewed by the Expert Review Committee. The comments and suggestions of the Review Committee were then sent back to the translators for corrections into the next intermediate Hindi version of the instrument. Then, the final translated copy was ready to be used for pilot testing. After pilot testing phase, the Hindi translated version of the CHIEF instrument, Hindi-CHIEF (H-CHIEF) instrument, was administered on a sample of 30 spinal cord injured subjects. The $\mathrm{H}$-CHIEF instrument was again administered to the subjects after 1 week to test test-rest reliability, intraclass correlation coefficient (ICC) $(2,1)$. The scores obtained in the retest was compared with the first score to calculate the ICC $(2,1)$. Twenty-five subjects were available to refill the CHIEF instrument for the $2^{\text {nd }}$ time.

An interview was conducted among the participants to find out the problems with the H-CHIEF instrument. The suggestions were incorporated in the final translated Hindi version tool, and the scale was sent to a panel of 10 rehabilitation experts to determine the content validity. The short version of the H-CHIEF scale was prepared by selection of 12 questions from the longer version.

Three methods of scoring each item were done as proposed by the original developers. ${ }^{[10]}$ The frequency with which barriers encountered were scored on a 5-point scale ( 0 - never; 1 - less than monthly; 2 - monthly; 3 - weekly; and 4 - daily), a 3-point scale ( 0 - no problem because the barrier was never encountered; 1 - a little problem; and 2 - a big problem) were used to measure the 
magnitude of the barrier. A frequency-magnitude product score was calculated as the product of the frequency score and the magnitude score. Total scores across the 25 items were calculated as the averages frequency-magnitude product score across all the scale items. A greater impact of environmental barriers was indicated by larger average frequency-magnitude product of all the items. The $\mathrm{H}-\mathrm{CHIEF}$ is given in appendix 1.

\section{Validity}

Content validity was determined by calculating the content validity ratio (CVR). It determined, if the skill or knowledge measured by this item was: essential (score $=1)$; useful, but not essential $($ score $=0)$, and not necessary (score $=-1$ ). CVR was calculated for each item based on a formula developed by Lawshe's. ${ }^{[11]}$ The rating of the scale was done by a panel of 10 experts in the field of neurological rehabilitation.

\section{Reliability}

The evaluation of internal consistency, test-rest reliability (ICC 2,1), standard error of measurement (SEM), and minimum detectable change (MDC) was done for both the longer and shorter version.

\section{Statistical analysis}

Statistical Package for Social Sciences (SPSS, IBM) for windows version 19 was used for the data analysis. Content validity was calculated using the CVR formula and content validity index (CVI) was also calculated. Reliability analysis was done for internal consistency by calculating the Cronbach's $\alpha$ value, test-retest reliability by ICC 2,1. The SEM and MDC were also determined as part of reliability analysis. The level of significance was set at $P \leq 0.05$.

\section{Content validity}

$\mathrm{CVR}=(\mathrm{Ne}-\mathrm{N} / 2) /(\mathrm{N} / 2)(\mathrm{Ne}-$ number of experts rated on item as essential, $\mathrm{N}$ - total no. of experts in the panel).

Calculated CVR were then compared to the levels required for statistical significance. A minimum CVR value of 0.62 was necessary for statistical significance based on 10 panelists, ${ }^{[11]}$ and the CVI was simply calculated as the mean of the CVR values of the retained items. A minimum score of 0.78 is required in CVI for the scale to be rated as having excellent content validity. ${ }^{[12]}$

\section{Internal consistency}

Evaluation of internal consistency (ICC) of H-CHIEF instrument for long and short version reliability was done by calculating the Cronbach's $\alpha \cdot{ }^{[13,14]}$ An $\alpha$ value $\geq 0.9$ is considered excellent and $\leq 0.5$ is unacceptable. ${ }^{[15]}$

\section{Test-retest reliability}

ICC 2,1; two-way random, absolute agreement, of measurements 1 and 2 were computed for determining the test-rest reliability. Test-retest reliability was considered to be acceptable if the ICC was $>0.75$ and considered to be very good if the ICC was $>0.9 .^{[16]}$

\section{Standard error of measurement}

The SEM was chosen as a measure of absolute reliability and was calculated by the formula, $S E M=S D \times \sqrt{ }(1-I C C)$, where SD is the standard deviation. A high SEM indicates a high level of error and indicates nonreproducibility of the measurements. ${ }^{[16]}$

\section{Minimum detectable change}

The MDC at $95 \%$ confidence was calculated to provide clinical interpretation, using the equation, $\mathrm{MDC}=\mathrm{SEM} \times 1.96 \times \sqrt{2}=2.77 \times \mathrm{SEM} \cdot{ }^{[17]}$

\section{Results}

The demographic characteristics of the subjects (mean $\pm \mathrm{SD}$ ) such as age, time since injury and frequency distribution (n) of type of paralysis, and ASIA scale levels is tabulated in Table 1 . The mean \pm SD, of individual items of $\mathrm{H}-\mathrm{CHIEF}$ instrument, a total score of the longer version $(1.44 \pm 0.82)$, and a total score of the shorter version $(1.07 \pm 0.66)$ is given in Table 2 . The (mean $\pm \mathrm{SD}$ ) of the subscales (attitudes/support, services and assistance, physical and structural, policies subscale work, and school subscale) of the H-CHIEF was also calculated and given in Table 3.

The content validity determined by the CVR was found to be 1 for all the items except item no. 5, 11, and 12 whose value was 0.8 . The CVI was calculated as a mean of the CVR values of the 25 items of the scale which was 0.97 and for the shorter version it was 0.98 [Table 4].

Table 1: Demographic details of the sample $(n=30)$

\begin{tabular}{lc}
\hline Variables & Mean \pm SD $/ \boldsymbol{n}$ \\
\hline Age (years) & $31.67 \pm 10.09$ \\
Time since injury (in month) & $29.87 \pm 25.28$ \\
Gender (male/female) & $26 / 4$ \\
Types of paralysis & \\
Quadriplegia & 14 \\
Paraplegia & 16 \\
Asia & \\
A & 7 \\
B & 13 \\
C & 7 \\
D & 3 \\
\hline SD: Standard deviation
\end{tabular}


Table 2: Mean \pm SD of individual and total scores across the 25 items (frequency-magnitude) for test-retest evaluation

\begin{tabular}{|c|c|c|}
\hline \multirow[t]{2}{*}{ Item number $(n)$} & \multicolumn{2}{|c|}{$\begin{array}{l}\text { Frequency } \times \text { magnitude } \\
\qquad \text { Mean } \pm S D\end{array}$} \\
\hline & Time 1 & Time 2 \\
\hline 1 & $1.75 \pm 2.23$ & $2.49 \pm 2.03$ \\
\hline 2 & $2.14 \pm 3.17$ & $2.49 \pm 2.31$ \\
\hline 3 & $1.03 \pm 1.70$ & $1.98 \pm 1.70$ \\
\hline 4 & $2.62 \pm 1.85$ & $3.13 \pm 1.19$ \\
\hline 5 & $2.17+1.85$ & $2.74+2.58$ \\
\hline 6 & $0.65 \pm 1.58$ & $0.96 \pm 1.78$ \\
\hline 7 & $0.10 \pm 0.30$ & $1.98 \pm 1.27$ \\
\hline 8 & $0.74 \pm 1.94$ & $2.32 \pm 1.37$ \\
\hline 9 & $0.55 \pm 1.12$ & $1.685 \pm 1.55$ \\
\hline 10 & $0.34 \pm 0.85$ & $1.55 \pm 0.86$ \\
\hline 11 & $0.86 \pm 2.06$ & $2.25 \pm 1.31$ \\
\hline 12 & $1.13 \pm 1.43$ & $1.62 \pm 1.31$ \\
\hline 13 & $0.86 \pm 0.78$ & $0.97 \pm 0.62$ \\
\hline 14 & $1.75 \pm 2.23$ & $1.95 \pm 1.32$ \\
\hline 15 & $1.82 \pm 2.26$ & $2.00 \pm 1.60$ \\
\hline 16 & $1.03 \pm 1.70$ & $2.09 \pm 1.44$ \\
\hline 17 & $2.62 \pm 1.85$ & $1.95 \pm 1.85$ \\
\hline 18 & $2.62 \pm 1.78$ & $1.75 \pm 1.95$ \\
\hline 19 & $2.54 \pm 0.82$ & $2.42 \pm 1.50$ \\
\hline 20 & $2.596 \pm 0.90$ & $1.92 \pm 1.48$ \\
\hline 21 & $1.78 \pm 1.08$ & $2.20 \pm 2.65$ \\
\hline 22 & $1.29 \pm 1.21$ & $1.75 \pm 0.68$ \\
\hline 23 & $1.08 \pm 1.31$ & $2.44 \pm 1.79$ \\
\hline 24 & $1.45 \pm 2.05$ & $1.89 \pm 1.65$ \\
\hline 25 & $1.60 \pm 1.41$ & $2.31 \pm 3.89$ \\
\hline Total (long) & $1.44 \pm 0.82$ & $2.01 \pm 0.45$ \\
\hline Total (short) & $1.07 \pm 0.66$ & $1.81 \pm 0.88$ \\
\hline
\end{tabular}

SD: Standard deviation

Internal consistency calculated by Cronbach's $\alpha$ value was found to be 0.92 and test-retest value (ICC 2,1) was $0.80(P<0.001)$. The MDC was found to be 0.99 and SEM was 0.36 for the longer version. The Cronbach's $\alpha$ was 0.731 , ICC 2,1 was $0.63(P<0.001)$, SEM was 0.24 , and MDC was 0.66 for the shorter version. The mean \pm SD of longer version and a shorter version for the total score obtained for test-retest reliability determination is given in Table 2.

\section{Discussion}

The CHIEF scale was designed to quantify environmental barriers perceived by people with disabilities. It helps in identifying major dimensions of the environment that may impede participation by people with disability such as accessibility, accommodation, resource availability, social support, and equality. It should be noted that the CHIEF does not measure environments and their characteristics objectively, but elicits a
Table 3: The $\left(\right.$ mean $\left._{ \pm} \mathrm{SD}\right)$ of the subscales H-CHIEF instrument

\begin{tabular}{|c|c|c|c|}
\hline Subscale & $\begin{array}{l}\text { Item number } \\
\text { in the CHIEF }\end{array}$ & Question & Mean \pm SD \\
\hline \multirow[t]{6}{*}{ Attitudes/support } & 20 & Support in community & $1.91 \pm 0.95$ \\
\hline & 17 & Attitudes in community & \\
\hline & 18 & Support in home & \\
\hline & 15 & Attitudes at home ${ }^{\#}$ & \\
\hline & 5 & Natural environment ${ }^{\#}$ & \\
\hline & 21 & Discrimination" & \\
\hline \multirow{7}{*}{$\begin{array}{l}\text { Services and } \\
\text { assistance }\end{array}$} & 1 & Transportation" & $0.91 \pm 0.66$ \\
\hline & 9 & Medical care ${ }^{\#}$ & \\
\hline & 12 & Help at home ${ }^{\#}$ & \\
\hline & 8 & Education/training & \\
\hline & 14 & Help in community & \\
\hline & 7 & Information" & \\
\hline & 10 & Personal equipment & \\
\hline \multirow{5}{*}{$\begin{array}{l}\text { Physical and } \\
\text { structural }\end{array}$} & 2 & Design of home & $1.51 \pm 0.92$ \\
\hline & 6 & Surroundings ${ }^{\#}$ & \\
\hline & 4 & Design of community & \\
\hline & 3 & Design of work/school & \\
\hline & 11 & Technology & \\
\hline \multirow[t]{4}{*}{ Policies subscale } & 23 & Policies of businesses\# & $1.17 \pm 0.70$ \\
\hline & 24 & $\begin{array}{l}\text { Policies of employment/ } \\
\text { education }\end{array}$ & \\
\hline & 22 & Services in community & \\
\hline & 25 & Policies of government $t^{\#}$ & \\
\hline \multirow{3}{*}{$\begin{array}{l}\text { Work and school } \\
\text { subscale }\end{array}$} & 19 & Support at work/school & $1.50 \pm 0.9$ \\
\hline & 16 & Attitudes at work/school ${ }^{\#}$ & \\
\hline & 13 & Help at work/school" & \\
\hline
\end{tabular}

of Environmental Factors instrument, SD: Standard deviation

characterization of the severity of perceived barriers to social participation, as reported by individuals with a disability. ${ }^{[6]}$

Several measures have been developed to quantify environmental facilitators (i.e., factors that increase participation) or barriers (i.e., factors that reduce participation) in people with disabilities such as the 84-item measure of the quality of the environment (MQE), the 61-item facilitators and barriers survey (FABS), and Quebec environmental assessment. ${ }^{[8,13,14]}$

However, these questionnaires are quite lengthy and require a long period of time for completion, which may not be feasible in daily clinical practice, particularly in community rehabilitation settings where the patient to therapist ratio is often high. Moreover, the MQE does not address the frequency of encountering environmental obstacles. ${ }^{[8]}$ The FABS, on the other hand, has shown only low to moderate internal consistency and test-retest reliability. ${ }^{[13]} \mathrm{CHIEF}$ also takes less time to administer compared with MQE and FABS as the items to be answered is less. 
Table 4: Content validity for the H-CHIEF instrument

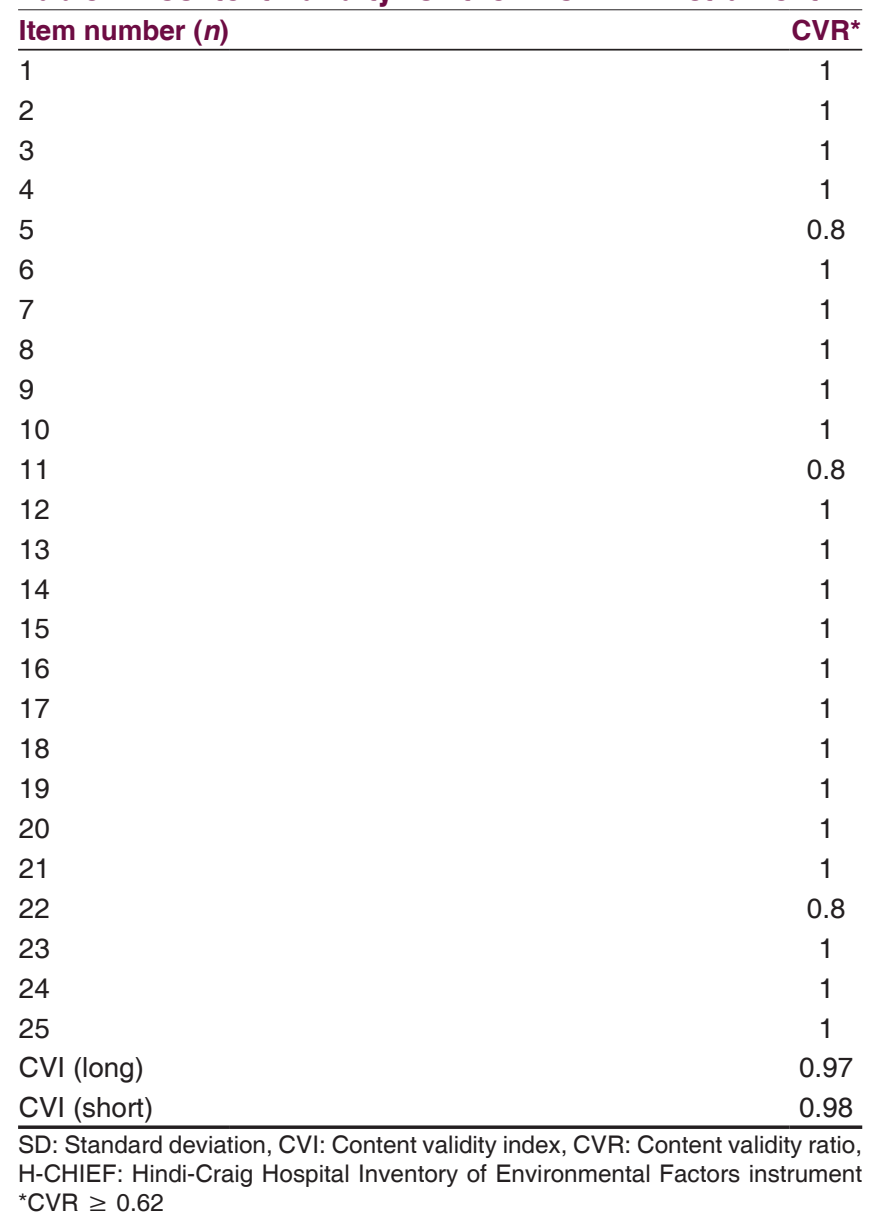

The results of the study had shown that H-CHIEF instrument possess good psychometric proprieties an assessment tool. The mean total value obtained was slightly higher than the previous reporting, which was $1.26^{[10]}$ where as in this study it is 1.44 . The subscale scores ranged from $0.91 \pm 0.66$ to $1.91 \pm 0.95$, the highest being for attitudes/support area. This indicates that the problem faced by the people with spinal cord injury which impede their movement is affected to a larger extent by the attitude and support in the community. The least problem is encountered in the service and assistance area.

The content validity determined by the CVR was found to be very high for both the versions of the scales. This indicates that the contents of scale appropriately measure the barriers and extent of the impact on the functioning. Quantitative reviews were conducted for determination of the content validity of the instrument. During the quantitative review of the scale, none of the items of the scale were rated as "not essential" by the reviewers. Items 5, 11, and 22 were rated as "useful but not essential" by the reviewers. The CVR indicated good content validity of the scale. In the qualitative review, the raters stated no discrepancies or issues over any of the items.

Internal consistency calculated by Cronbach's $\alpha$, test-retest value (ICC 2,1) and MDC were found higher for the longer version and SEM was smaller for the short version. Internal consistency reliability shows high-reliability score as that of the original scale and Chinese version. ${ }^{[2,6]}$ The test-retest value was also high as that of the previous reporting. ${ }^{[6]}$ Small estimations of SEM for both versions of the scales indicate that scores obtained were reproducible again. MDC provides an assessment of a relative improvement or deterioration. It would be beneficial to the clinician to determine whether there was true change over time with intervention. ${ }^{[18]}$ The SEM was very small for both the versions of the scale indicating that the scores obtained are steady and reproducible again.

Better evaluation leads to better and accurate outcomes. The H-CHIEF will help the clinicians and rehabilitation team members of the spinal cord injured to measure the environmental barriers perceived by the spinal cord injury patients and help them to make realistic goals for the patients. The development of the scale in Hindi ensures that it would be easy to understand and comprehend the scale. A large number of people live in rural hinterlands of India; the particular scale will be highly useful in assessing the barriers they face in everyday life. They will be asked about their problem in native language, and this will be very effective as the meaning of the questions will not be lost during self-translations by the examiner. The H-CHIEF can also be used to make international comparisons and cross-cultural research studies.

The translation of the CHIEF into Hindi was done by Beaton manual guidelines. The Beaton manual is an accepted and widely used procedure for translation. The estimation of content validity and internal consistency was only done. Further studies can be done to calculate other psychometric properties of the scale.

\section{Conclusion}

The long and short Hindi CHIEF instrument has been found to have adequate content validity, internal consistency, test-retest reliability, and SEM on spinal cord injured population. The instrument can be used to assess environmental barriers perceived by spinal cord injury patients. 


\section{Financial support and sponsorship}

Nil.

\section{Conflicts of interest}

There are no conflicts of interest.

\section{References}

1. Maynard FM Jr, Bracken MB, Creasey G, Ditunno JF Jr, Donovan WH, Ducker TB, et al. International standards for neurological and functional classification of spinal cord injury. American Spinal Injury Association. Spinal Cord 1997;35:266-74.

2. Liao LR, Lau RW, Pang MY. Measuring environmental barriers faced by individuals living with stroke: Development and validation of the Chinese version of the Craig Hospital Inventory of Environmental Factors. J Rehabil Med 2012;44:740-6.

3. Kennedy P, Lude P, Taylor N. Quality of life, social participation, appraisals and coping post spinal cord injury: A review of four community samples. Spinal Cord 2006;44:95-105.

4. Dijkers M. Community integration conceptual issues and measurement approaches in rehabilitation research. Top Spinal Cord Inj Rehabil 1998;4:1-15.

5. International Classification of Functioning, Disability and Health (ICF). Available from: http://www.who.int/classifications/icf/en/. [Last accessed on 2015 Mar 12].

6. Whiteneck GG, Harrison-Felix CL, Mellick DC, Brooks CA, Charlifue SB, Gerhart KA. Quantifying environmental factors: A measure of physical, attitudinal, service, productivity, and policy barriers. Arch Phys Med Rehabil 2004;85:1324-35.

7. Chhabra HS, Arora M. Demographic profile of traumatic spinal cord injuries admitted at Indian Spinal Injuries Centre with special emphasis on mode of injury: A retrospective study. Spinal Cord 2012;50:745-54.

8. Fougeyrollas P, Noreau L, St-Michel G. Measure of the quality of the environment - Version 1.0. Lac St-Charles, Quebec, Canada: CQCIDIH; 1997.

9. Beaton DE, Bombardier C, Guillemin F, Ferraz MB. Guidelines for the process of cross-cultural adaptation of self-report measures. Spine (Phila Pa 1976) 2000;25:3186-91.

10. Craig Hospital Inventory of Environmental Factors (CHIEF) Manual, Version 3.0. Craig Hospital; April, 2001. Available from: https:// www.craighospital.org/uploads/CraigHospital.ChiefManual.pdf. [Last accessed on 2015 Mar 12].

11. Lawshe CH. A quantitative approach to content validity. Pers Psychol 1975;28:563-75.

12. Polit DF, Beck CT. The content validity index: Are you sure you know what's being reported? Critique and recommendations. Res Nurs Health 2006;29:489-97.

13. Gray DB, Hollingsworth HH, Stark S, Morgan KA. A subjective measure of environmental facilitators and barriers to participation for people with mobility limitations. Disabil Rehabil 2008;30:434-57.

14. Fougeyrollas P. Documenting environmental factors for preventing the handicap creation process: Quebec contributions relating to ICIDH and social participation of people with functional differences. Disabil Rehabil 1995;17:145-53.

15. Bland JM, Altman DG. Cronbach's alpha. BMJ 1997;314:572.

16. Weir JP. Quantifying test-retest reliability using the intraclass correlation coefficient and the SEM. J Strength Cond Res 2005;19:231-40.

17. Haley SM, Fragala-Pinkham MA. Interpreting change scores of tests and measures used in physical therapy. Phys Ther 2006;86:735-43.

18. Fritz SL, Blanton S, Uswatte G, Taub E, Wolf SL. Minimal detectable change scores for the Wolf Motor Function Test. Neurorehabil Neural Repair 2009;23:662-7.

\section{Staying in touch with the journal}

1) Table of Contents (TOC) email alert Receive an email alert containing the TOC when a new complete issue of the journal is made available online. To register for TOC alerts go to www.ruralneuropractice.com/signup.asp.

\section{2) RSS feeds}

Really Simple Syndication (RSS) helps you to get alerts on new publication right on your desktop without going to the journal's website. You need a software (e.g. RSSReader, Feed Demon, FeedReader, My Yahoo!, NewsGator and NewzCrawler) to get advantage of this tool. RSS feeds can also be read through FireFox or Microsoft Outlook 2007. Once any of these small (and mostly free) software is installed, add www.ruralneuropractice.com/rssfeed.asp as one of the feeds. 


\section{Appendix 1}

\section{क्रैग हॉस्पिटल इन्वेंटरी ऑफ इन्वॉयर्नमेंटल फैक्टर्स-हिन्दी (c) (जानकारी के लिए: drsandeepsoni@gmail.com या shef0604@gmail.com पर सम्पर्क करें)}

समाज के एक सक्रिय, उत्पादक सदस्य होने के नाते कुछ इस तरह के कार्यों में भागीदारी करना शामिल है, जैसे- कामकाज करना, स्कूल जाना, अपने घर की देखभाल करना तथा समुदाय में सामाजिक, मनोरंजक और नागरिक गतिविधियों में परिवार और मित्रों के साथ शामिल होना। इन गतिविधियों में किसी व्यक्ति की भागीदारी में कई कारक मदद या सुधार कर सकते हैं, जबकि दूसरी ओर कुछ ऐसे कारक भी हैं जो अवरोधों की तरह कार्य करते हैं और भागीदारी को सीमित करते हैं। सबसे पहले, क्या आपको लगता है कि जिस तरह से दूसरे लोगों को भागीदारी करने और निम्न से लाभ उठाने के मौके मिले हैं, आपको भी इस तरह के अवसर प्राप्त हुए हैं:

$\begin{array}{lll}\text { शिक्षा } & - \text { हां } & \text {-नहीं } \\ \text { रोजगार } & - \text { हां } & \text {-नहीं } \\ \text { मनोरंजन / अवकाश } & - \text { हां } & \text {-नहीं }\end{array}$

कृप्या पहले आप मुझे यह बताएं कि निम्न में से प्रत्येक, कितनी बार गतिविधियों में आपकी स्वयं की भागीदारी के लिए एक रूकावट रहा है, जिससे आप पर असर पड़ता है। पिछले वर्ष के बारे में विचार करें, और मुझे बताएं कि नीचे सूची में निम्न प्रत्येक विषय आपके लिए किस तरह एक समस्या रहा है, दैनिक, साप्ताहिक, मासिक, एक माह से कम, या कभी नहीं। यदि विषय एक समस्या के रूप में आप के सामने आता है, तो यह बताएं कि जो गतिविधियां आपको प्रभावित करती हैं, उनमें आप की भागीदारी से संबंधित विषय आपके लिए कितनी बड़ी समस्या है। (नोटः यदि किसी प्रश्न में विशेष रूप से स्कूल या कार्य के बारे में पूछा गया है और आप न तो स्कूल जाते हैं और न ही कार्यरत हैं, तो 'लागू नहीं' पर टिक करें)

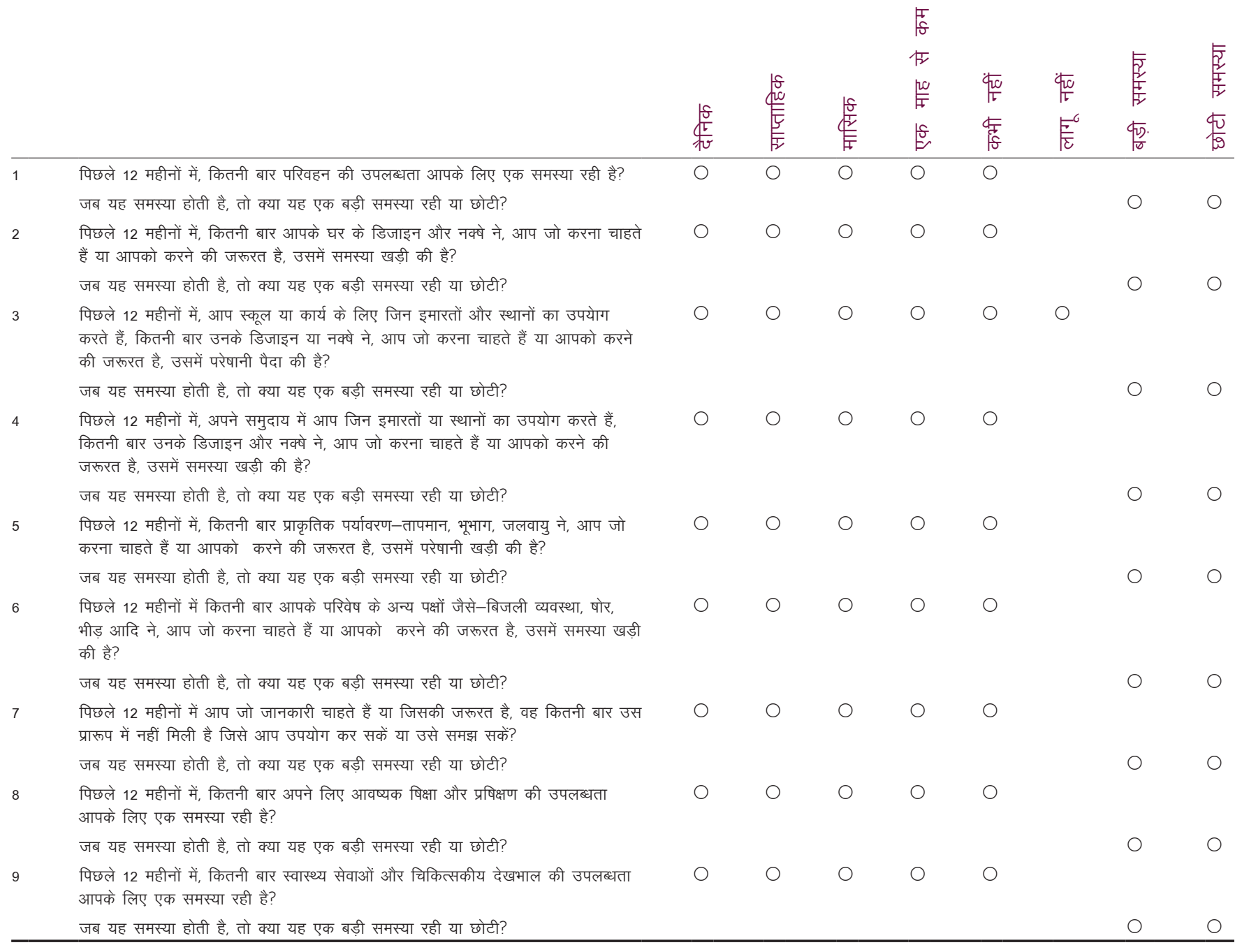




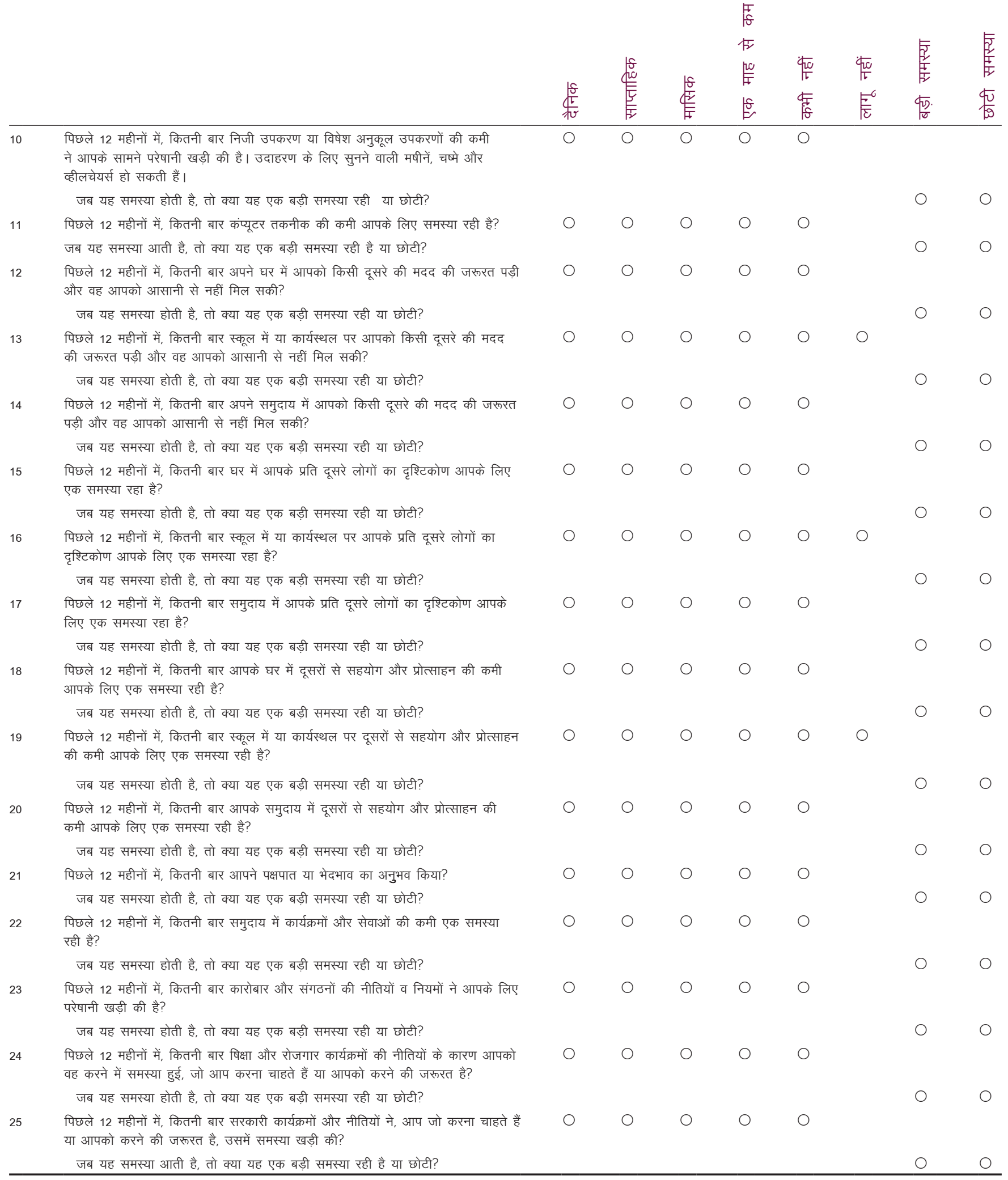




\section{क्रैग हॉस्पिटल इन्वेंटरी ऑफ इन्वॉयर्नमेंटल फैक्टर्स पॉर्ट फॉर्म- हिन्दी}

\section{(C) (जानकारी के लिए: drsandeepsoni@gmail.com या shef0604@gmail.com पर सम्पर्क करें)}

समाज के एक सक्रिय, उत्पादक सदस्य होने के नाते कुछ इस तरह के कार्यों में भागीदारी करना षामिल है, जैसे- कामकाज करना, स्कूल जाना, अपने घर की देखभाल करना तथा समुदाय में सामाजिक, मनोरंजक और नागरिक गतिविधियों में परिवार और मित्रों के साथ षामिल होना। इन गतिविधियों में किसी व्यक्ति की भागीदारी में कई कारक मदद या सुधार कर सकते हैं, जबकि दूसरी ओर कुछ ऐसे कारक भी हैं जो अवरोधों की तरह कार्य करते हैं और भागीदारी को सीमित करते हैं। सबसे पहले, क्या आपको लगता है कि जिस तरह से दूसरे लोगों को भागीदारी करने और निम्न से लाभ उठाने के मौके मिले हैं, आपको भी इस तरह के अवसर प्राप्त हुए हैं:

कृप्या पहले आप मुझे यह बताएं कि निम्न में से प्रत्येक, कितनी बार गतिविधियों में आपकी स्वयं की भागीदारी के लिए एक रूकावट रहा है, जिससे आप पर असर पड़ता है। है। पिछले वर्श के बारे में विचार करें, और मुझे बताएं कि नीचे सूची में निम्न प्रत्येक विशय आपके लिए किस तरह एक समस्या रहा है, दैनिक, साप्ताहिक, मासिक, एक माह से कम, या कभी नहीं। यदि विशय एक समस्या के रूप में आप के सामने आता है, तो यह बताएं कि जो गतिविधियां आपको प्रभावित करती हैं, उनमें आप की भागीदारी से संबंधित विशय आपके लिए कितनी बड़ी समस्या है।

(नोट: यदि किसी प्रष्न में विषेश रूप से स्कूल या कार्य के बारे में पूछा गया है और आप न तो स्कूल जाते हैं और न ही कार्यरत हैं, तो 'लागू नहीं' पर टिक करें)

\begin{tabular}{|c|c|c|c|c|c|c|c|c|c|}
\hline & & 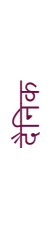 & 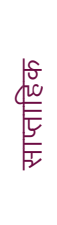 & $\frac{\sqrt{\frac{1}{2}}}{\frac{1}{1}}$ & 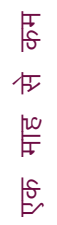 & 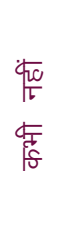 & $\begin{array}{l}\sqrt{\bar{c}} \\
\bar{\sigma}^{\circ} \\
\bar{E}\end{array}$ & $\begin{array}{l}\sqrt{\frac{1}{2}} \\
\frac{1}{2} \\
\sqrt{\frac{2}{0}}\end{array}$ & $\begin{array}{l}\frac{\sqrt{2}}{2} \\
\frac{5}{2}\end{array}$ \\
\hline \multirow[t]{2}{*}{1} & $\begin{array}{l}\text { पिछले } 12 \text { महीनों में, कितनी बार परिवहन की उपलब्धता आपके लिए एक } \\
\text { समस्या रही है? }\end{array}$ & O & $\bigcirc$ & $\bigcirc$ & O & $\bigcirc$ & & & \\
\hline & जब यह समस्या होती है, तो क्या यह एक बड़ी समस्या रही या छोटी? & & & & & & & 0 & 0 \\
\hline \multirow[t]{2}{*}{2} & $\begin{array}{l}\text { पिछले } 12 \text { महीनों में, कितनी बार प्राकृतिक पर्यावरण-तापमान, भूभाग, } \\
\text { जलवायु ने, आप जो करना चाहते हैं या आपको करने की जरूरत है, } \\
\text { उसमें परेषानी खड़ी की है? }\end{array}$ & ○ & $\bigcirc$ & $\bigcirc$ & $\bigcirc$ & $\bigcirc$ & & & \\
\hline & जब यह समस्या होती है, तो क्या यह एक बड़ी समस्या रही या छोटी? & & & & & & & 0 & 0 \\
\hline \multirow[t]{2}{*}{3} & $\begin{array}{l}\text { पिछले } 12 \text { महीनों में कितनी बार आपके परिवेष के अन्य पक्षों जैसे-बिजली } \\
\text { व्यवस्था, षोर, भीड़ आदि ने, आप जो करना चाहते हैं या आपको करने } \\
\text { की जरूरत है, उसमें समस्या खड़ी की है? }\end{array}$ & O & $\bigcirc$ & $\bigcirc$ & $\bigcirc$ & $\bigcirc$ & & & \\
\hline & जब यह समस्या होती है, तो क्या यह एक बड़ी समस्या रही या छोटी? & & & & & & & $\bigcirc$ & 0 \\
\hline \multirow[t]{2}{*}{4} & $\begin{array}{l}\text { आप जो जानकारी चाहते हैं या आपको जिसकी जरूरत है, वह पिछले } \\
12 \text { महीनों में कितनी बार आपको उस प्रारूप में नहीं मिली है जिसमें आप } \\
\text { उपयोग कर सकें या उसे समझ सकें? }\end{array}$ & O & $\bigcirc$ & $\bigcirc$ & $\bigcirc$ & $\bigcirc$ & & & \\
\hline & जब यह समस्या होती है, तो क्या यह एक बड़ी समस्या रही या छोटी? & & & & & & & $\bigcirc$ & $\bigcirc$ \\
\hline \multirow[t]{2}{*}{5} & $\begin{array}{l}\text { पिछले } 12 \text { महीनों में, कितनी बार स्वास्थ्य सेवाओं और चिकित्सकीय } \\
\text { देखभाल की उपलब्धता आपके लिए एक समस्या रही है? }\end{array}$ & O & $\bigcirc$ & $\bigcirc$ & O & $\bigcirc$ & & & \\
\hline & जब यह समस्या होती है, तो क्या यह एक बड़ी समस्या रही या छोटी? & & & & & & & $\bigcirc$ & 0 \\
\hline \multirow[t]{2}{*}{6} & $\begin{array}{l}\text { पिछले } 12 \text { महीनों में, कितनी बार अपने घर में आपको किसी दूसरे की } \\
\text { मदद की जरूरत पड़ी और वह आपको आसानी से नहीं मिल सकी? }\end{array}$ & ○ & $\bigcirc$ & $\bigcirc$ & ○ & $\bigcirc$ & & & \\
\hline & जब यह समस्या होती है, तो क्या यह एक बड़ी समस्या रही या छोटी? & & & & & & & $\bigcirc$ & $\bigcirc$ \\
\hline \multirow[t]{2}{*}{7} & $\begin{array}{l}\text { पिछले } 12 \text { महीनों में, कितनी बार र्कूल में या कार्यस्थल पर आपको किसी } \\
\text { दूसरे की मदद की जरूरत पड़ी और वह आपको आसानी से नहीं मिल } \\
\text { सकी? }\end{array}$ & O & $\bigcirc$ & $\bigcirc$ & O & $\bigcirc$ & O & & \\
\hline & जब यह समस्या होती है, तो क्या यह एक बड़ी समस्या रही या छोटी? & & & & & & & $\bigcirc$ & O \\
\hline \multirow[t]{2}{*}{8} & $\begin{array}{l}\text { पिछले } 12 \text { महीनों में, कितनी बार घर में आपके प्रति दूसरे लोगों का } \\
\text { दृश्टिकोण आपके लिए एक समस्या रहा है? }\end{array}$ & O & $\bigcirc$ & $\bigcirc$ & $\bigcirc$ & $\bigcirc$ & & & \\
\hline & जब यह समस्या होती है, तो क्या यह एक बड़ी समस्या रही या छोटी? & & & & & & & $\bigcirc$ & 0 \\
\hline \multirow[t]{2}{*}{9} & $\begin{array}{l}\text { पिछले } 12 \text { महीनों में, कितनी बार स्कूल में या कार्यस्थल पर आपके प्रति } \\
\text { दूसरे लोगों का दृश्टिकोण आपके लिए एक समस्या रहा है? }\end{array}$ & O & $\bigcirc$ & $\bigcirc$ & $\bigcirc$ & $\bigcirc$ & $\bigcirc$ & & \\
\hline & जब यह समस्या होती है, तो क्या यह एक बड़ी समस्या रही या छोटी? & & & & & & & $\bigcirc$ & $\bigcirc$ \\
\hline \multirow[t]{2}{*}{10} & $\begin{array}{l}\text { पिछले } 12 \text { महीनों में, कितनी बार आपने पक्षपात या भेदभाव का सामना } \\
\text { किया? }\end{array}$ & O & $\bigcirc$ & $\bigcirc$ & $\bigcirc$ & $\bigcirc$ & & & \\
\hline & जब यह समस्या होती है, तो क्या यह एक बड़ी समस्या रही या छोटी? & & & & & & & 0 & 0 \\
\hline
\end{tabular}



नीतियों व नियमों ने आपके लिए परेषानी खड़ी की है?

और संगठनों की

जब यह समस्या होती है, तो क्या यह एक बड़ी समस्या रही या छोटी?

12 पिछले 12 महीनों में, कितनी बार सरकारी कार्यक्रमों और नीतियों ने, आप जो करना चाहते हैं या आपको करने की जरूरत है, उसमें समस्या खड़ी की? 